\title{
Pengaruh Komunikasi Dan Disiplin Kerja Terhadap Kinerja Karyawan Pada PT. Hokben Alam Sutera Tangerang
}

\author{
Retno Japanis Permatasari \\ Dosen Fakultas Ekonomi Universitas Pamulang \\ Email : dosen01337@unpam.ac.id
}

\begin{abstract}
ABSTRAK
Tujuan Penelitian ini adalah untukmengetahui pengaruh komunikasi terhadap kinerja karyawan pada PT. Hokben Alam Sutera Tangerang, untuk mengetahui pengaruh disiplin kerja terhadap kinerja karyawan pada PT. Hokben Alam Sutera Tangerang, untuk mengetahui pengaruh komunikasi dan disiplin kerja terhadap kinerja karyawan pada PT. Hokben Alam Sutera Tangerang.

Metode penelitian yang digunakan adalah Metode analisis deskriptif dengan pendekatan kuantitatif, sedangkan pengolahan data menggunakan program SPSS versi 21.0 menggunakan sampel jenuh dengan semua populasi dijadikan sampeldalam penelitian ini sebanyak 50 karyawan. Metode pengumpulan data dengan menggunakan data primer berupa kuesioner dan data sekunder. Metode analisis data dengan menggunakan uji validitas, uji reliabilitas, uji asumsi klasik, uji korelasi, uji determinasi, uji regresi linier berganda dan uji hipotesis.

Pengaruh komunikasi dan disiplin kerja terhadap kinerja karyawan pada PT. Hokben Alam Sutera Tangerang berdasarkan hasil analisa data menunjukkan bahwa dari hasil korelasi sebesar 0,651 dapat disimpulkan bahwa terdapat pengaruh yang kuat antara komunikasi dan disiplin kerja terhadap kinerja karyawan.Hasil koefisien determinasi menunjukkan bahwa pengaruh komunikasi memberikan kontribusi sebesar 42,3\% terhadap kinerja karyawan, sisanya sebesar 57,7\% dipengaruhi oleh variabel lain. Persamaan regresi linear berganda $Y=1,070+0,153$ $\mathrm{X} 1+0,602 \mathrm{X} 2$ dapat disimpulkan bahwa jika pengaruh komunikasi dan disiplin kerja ditingkatkan satu satuan maka kinerja karyawan akan meningkat. Dari hasil pengujian statistik di dapat bahwa Fhitung > Ftabel yaitu didapat bahwa 17,257 > 2,81 dengan tingkat signifikasi $0,000<0,05$ sehingga dapat disimpulkan bahwa terdapat pengaruh yang signifikan antara komunikasi (X1) dan disiplin kerja (X2) secara simultan terhadap kinerja karyawan (Y).
\end{abstract}

\section{Kata Kunci : Komunikasi, Disiplin Kerja dan Kinerja Karyawan}




\section{PENDAHULUAN}

\section{Latar Belakang}

Dalam sebuah perusahaan, kinerja karyawan merupakan salah satu faktor utama untuk meningkatkan produktivitas perusahaan.Kinerja karyawan tersebut ditunjang oleh beberapa faktor, salah satunya dengan komunikasi.Untuk mendukung dan meningkatkan kinerja karyawan, diperlukan adanya komunikasi yang efektif, sehingga kinerja karyawan dapat berjalan dengan maksimal.Untuk mewujudkan komunikasi yang efektif diperlukan transmisi data dan keterampilan tertentu dari pengirim dan penerima informasi.Keterampilan tersebut meliputi keterampilan membaca, menulis, mendengar, berbicara dan lain-lain.

Menurut Yosal Iriantara (2014:44), komunikasi merupakan suatu proses penyampaian pesan berupa informasi, gagasan, pikiran, pendapat, pengetahuan, ungkapan perasaan untuk tujuan tertentu. pemindahan informasi atau gagasan dari seseorang ke orang lain, dapat berlangsung secara lisan maupun tulisan, dan dapat dilakukan oleh dua orang atau lebih. Kurangnya komunikasi akan menjadi kendala yang berpengaruh bagi kelancaran aktivitas perusahaan.

Dalam tempat kerja, antara manajer dan karyawan dihubungkan dengan komunikasi untuk melaksanakan tugas masing-masing agar dapat terselesaikan dengan baik. Kurangnya komunikasi akan menjadi kendala yang berpengaruh bagi kelancaran aktivitas perusahaan, Dapat di lihat dengan adanya miscommunicationantar karyawan yang terjadi karena perbedaan persepsi antara informasi yang disampaikan komunikator dengan informasi yang diterima komunikan. Komunikasi yang baik akan memberikan dampak positif bagi manajer maupun karyawan. Demikian Juga komunikasi antar karyawan yang kurang baik dengan sering terjadinya kesalahan dalam pembuatan orderan customer yang selalu salah pembuatannya, sehingga menimbulkan complain atau masalah dengan customer begitu juga menimbulkan masalah antar karyawan. Dalam pelaksanaan tugas, mereka cenderung berkomunikasi secara lisan dibandingkan dengan komunikasi secara tertulis,karena dengan komunikasi secara lisan akan mempermudah terjadinya umpan balik, sehingga ketidakjelasan informasi dapat langsung teratasi dengan menanyakan secara langsung.

Ketidakhadiran karyawan menjadikan sesuatu yang sangat penting atau disebut mahal karena ketidakhadiran dapat menyebabkan pekerjaan menjadi terbengkalai. Akibatnya terjadi penumpukan tugas-tugas yang seharusnya dapat diselesaikan dalam satu shift tertentu, namun tugas tersebut akhirnya dilimpahkan kepada rekan kerja shift selanjutnya, sehingga menyebabkan kinerja karyawan terganggu akibat adanya pelimpahan tugas tersebut. 
Penurunan kinerja karyawan ditunjukkan dengan banyaknya complain dan keterlambatan delivery. Banyak hal yang terjadi dalam penurunan tersebut seperti menurunnya kualitas kerja, kecepatan kerja, inisiatif kerja karyawan menjadi berkurang sehingga kurang pedulinya dengan kerjaannya masing-masing kurang bertanggung jawab atas pekerjaannya.Ketidakhadiran

karyawan merupakan sikap dari rendahnya kedisiplinan yang dapat menurunkan tingkat kualitas kerja. Dengan menurunnya kualitas kerja akan menyebabkan perusahaan menjadi lambat untuk maju.

Karena dengan adanya komunikasi yang baik akan menghasilkan informasi tentang perusahaan dari seorang manajer atau atasan bagi karyawan untuk bekerja lebih baik namun tanpa adanya disiplin kerja maka kinerja karyawan tidak akan maksimal. Jadi adanya kemauan juga harus diiringi dengan adanya disiplin kerja sehingga akan menghasilkan kinerja karyawan yang baik bagi perusahaan. Berdasarkan latar belakang di atas maka peneliti memberi judul tugas akhir ini "PENGARUH KOMUNIKASI DAN DISIPLIN KERJA TERHADAP KINERJA KARYAWAN PADA PT HOKBEN ALAM SUTERA TANGERANG"

\section{Identifikasi Masalah}

Berdasarkan latar belakang tersebut maka dapat di identifikasi masalah sebagai berikut:

a. Masih kurangnya pemahaman karyawan tentang informasi standaritas perusahaan. b. Kurangnya komunikasi antara pimpinan dan karyawan.

c. Kurangnya keteladanan dari pimpinan perusahaan.

d. Tingkat absensi karyawan masih rendah.

e. Kualitas kerja karyawan menurun.

f. Kemampuan kerja sama antara karyawan masih di rasa kurang.

3. Rumusan Masalah

Melihat dari identifikasi masalah, maka penulis merumuskan sebagai berikut :

a. Bagaimana pengaruh komunikasi terhadap kinerja karyawan pada PT. Hokben Alam Sutera Tangerang?

b. Bagaimana pengaruh disiplin kerja terhadap kinerja karyawan pada PT. Hokben Alam Sutera Tangerang?

c. Seberapa besar pengaruh komunikasi dan disiplin kerja terhadap kinerja karyawan pada PT. Hokben Alam Sutera Tangerang?

\section{TINJAUAN PUSTAKA}

\section{Komunikasi}

Komunikasi merupakan salah satu kegiatan interaksi yang sangat penting dalam kehidupan sosial manusia, karena seluruh kegiatan manusia, di mulai dengan komunikasi.

Menurut Effendy (2009:9), istilah komunikasi atau dalam bahasa inggris communication berasal dari kata latincommunication, dan bersumber dari kata communts yang berarti sama makna. Jadi, kalau dua orang terlihat dalam komunikasi, misalnya dalam bentuk percakapan, makna 
komunikasi akan terjadi atau berlangsung selama ada kesamaan makna mengenai apa yang di percakapkan.

Menurut

(2012:272), komunikasi adalah pemindahan pengertian dalam bentuk gagasan atau informasi dari seseorang ke orang lain. Perpindahan pengertian tersebut melibatkan lebih dari sekedar katakata yang digunakan dalam percakapan, tetapi juga ekspresi wajah, intonasi, titik putus vokal dan sebagainya.

\section{Disiplin}

Disiplin adalah perasaan taat dan patuh terhadap nilai-nilai yang di percaya termasuk melakukan pekerjaan tertentu yang menjadi tanggung jawabnya. Manusia sebagai makhluk hidup terkadang ingin hidup bebas, sehingga ia ingin melepaskan dari segala ikatan dan peraturan yang membatasi kegiatan dan perilakunya. Namun manusia makhluk social yang hidup di antara individu-individu lain, di mana ia mempunyai kebutuhan akan perasaan di terima orang lain. Edi Sutrisno

(2014:98) mengatakan disiplin adalah sikap kesediaan dan kerelaan seseorang untuk mematuhi dan mentaati norma-norma peraturan yang berlaku disekitarnya. Disiplin karyawan baik akan mempercepat tujuan perusahaan, sedangkan yang merosot akan menjadi penghalang dan memperlambat percapaian tujuan perusahaan. Kedisiplinan merupakan fungsi operatif manajemen sumber daya manusia yang terpenting karena semakin baik disiplin karyawan yang baik, mudah bagi organisasi atau perusahaan mencapai hasil yang maksimal.

Menurut Mangkunegara (2013:129) mengemukakan bahwa dicipline is management action to enfore organization standars. Berdasarkan pendapat tersebut, disiplin kerja dapat diartikan pelaksanaan manajemen untuk memperteguh pedomanpedomanorganisasi.Menurut

Simamora (2006:610), disiplin adalah prosedur yang mengoreksi atau menghukum bawahan karena melanggar peraturan atau prosedur.

Menurut Hasibuan (2016:143), mengatakan bahwa kedisiplinan adalah kesadaran atau kesediaan seseorang untuk menaati semua peraturanperaturan dan norma-norma sosial yang berlaku. Kesadaran itu sendiri dalam sikap seseorang yang sukarela untuk menaati semua peraturan dan sadar akan tugas dan tanggung jawabnya. Sehingga akan mematuhi/mengerjakan semuanya tugas dengan baik, buka atas paksaan. Sedangkan kesediaan adalah suatu sikap, tingkah laku dan perbuatan seseorang yang sesuai dengan peraturan perusahaan, baik yang tertulis maupun yang tidak tertulis.

\section{Kinerja}

Kinerja secara harfiah berasal dari kata "kerja" yang menurut kamus besar bahasa Indonesia (1993: 428) berarti kegiatan melakukan sesuatu. Dengan bekerja seseorang akan mendapatkan sesuatu dari hasil kerjanya. Hasil kerja baik saat 
proses kerja maupun setelah proses kerja ini bisa dikatakan kinerja. Kinerja adalah hasil kerja yang dapat dicapai oleh seseorang atau kelompok orang dalam suatu perusahaan sesuai dengan wewenang dan tanggung jawab masing-masing dalam upaya pencapaian tujuan perusahaan secara legal, tidak melanggar hukum dan tidak bertentangan dengan moral atau etika.

Menurut pandangan Byars dalam Meithiana Indrasari (2017:50), bahwa kinerja merupakan hasil keterkaitan antara usaha, kemampuan dan persepsi tugas. Kinerja yang tinggi sebagai suatu langkah untuk menuju pada proses tercapainya tujuan organisasi bersangkutan. Oleh karena itu, diperlukan upaya untuk meningatkan kinerja tersebut.

Menurut Anwar Prabu Mangkunegara (2015:67), mengemukakan bahwa kinerja adalah hasil kerja secara kualitas dan kuantitas yang dicapai oleh seorang pegawai dalam melaksanakan tugasnya sesuai dengan tanggung jawab yang diberikan kepadanya.

Sedangkan menurut Wilson Bangun (2015:231), kinerja (Performance) adalah hasil pekerjaan yang dihasilkan seseorang berdasarkan persyaratan-persyaratan pekerjaan (job requirement). Suatu pekerjaan mempunyai persyaratan tertentu untuk dapat dilakukan dalam mencapai tujuan yang disebut juga sebagai standar pekerjaan (job standard).

\section{METODE PENELITIAN}

Metode penelitian yang digunakan adalah Metode analisis deskriptif dengan pendekatan kuantitatif, sedangkan pengolahan data menggunakan program SPSS versi 21.0 menggunakan sampel jenuh dengan semua populasi dijadikan sampeldalam penelitian ini sebanyak 50 karyawan. Metode pengumpulan data dengan menggunakan data primer berupa kuesioner dan data sekunder. Metode analisis data dengan menggunakan uji validitas, uji reliabilitas, uji asumsi klasik, uji korelasi, uji determinasi, uji regresi linier berganda dan uji hipotesis.

\section{PEMBAHASAN}

Komunikasi merupakan suatu proses penyampaian pesan berupa informasi, gagasan, pikiran, pendapat, pengetahuan, ungkapan perasaan untuk tujuan tertentu. Pemindahan informasi atau gagasan dari seseorang ke orang lain, dapat berlangsung secara lisan maupun tulisan, dan dapat dilakukan oleh dua orang atau lebih.

Kurangnya komunikasi akan menjadi kendala yang berpengaruh bagi kelancaran aktivitas perusahaan.

Disiplin kerja adalah suatu sikap menghormati, menghargai, patuh dan taat terhadap peraturanperaturan yang berlaku, baik yang tertulis maupunyang tidak tertulis serta sanggup menjalankannya dan tidak mengelak untuk menerima sanksi-sanksi apabila ia melanggar tugas dan wewenang yang diberikan kepadanya. Disiplin kerja sangat penting karena dengan karyawan mempunyai disiplin kerja maka akan menghasilkan kualitas kerja, 
kuantitas kerja dan waktu kerja yang baik sehingga dapat meningkatkan kinerja karyawan.Berdasarkan penelitian yang telah dilakukan dan diperoleh hasil sebagai berikut:

\section{Hasil Analisis data}

Berdasarkan karakteristik responden diketahui bahwa dari 50 responden atau karyawan padaPT. Hokben Alam Sutera Tangerang. Terdiri dari laki-laki sebanyak 35orang $(70 \%)$ dan perempuan sebanyak 15 orang (30\%), usia responden terdiri dari usia 21-25 sebanyak 28 orang (56\%), dan 2630 sebanyak 15 orang $(30 \%)$, dan 31-35 sebanyak 7 orang (14\%) pendidikan di mulai dari SMA/SMK sebanyak 44 orang $(88 \%$,) D III sebanyak 2 orang (4\%) dan S1 sebanyak 4 orang $(8 \%)$, lama bekerja $<5$ sebanyak 20 orang $(40 \%),>5$ sebanyak 30 orang $(60 \%)$.

2. Hasil Analisis Komunikasi dan Disiplin Kerja

Berdasarkan hasil analisa regresi linear berganda diketahui bahwa pengaruh komunikasi dan disiplin kerja terhadap kinerja karyawan pada PT. Hokben Alam Sutera Tangerang yang ditunjukan oleh $\mathrm{Y}=1,070+0,153 \mathrm{X} 1+0,602$ $\mathrm{X} 2$. Hasil ini mengindentifikasikan nilai konstanta sebesar 1,070 menyatakan bahwa jika tidak ada variabel komunikasi maka nilai variabel kinerja karyawan pada PT. Hokben Alam Suetra Tangerang adalah sebesar 1,070. Sedangkan nilai koefisien regresi sebesar 0,153 dan 0,602 menyatakan bahwa setiap peningkatan satu satuan pada variabel komunikasi dan disiplin kerja akan mempengaruhi peningkatkan satu satuan pada variabel kinerja kerja karyawan padaPT. Hokben Alam Sutera sebesar 0,153 dan 0,602.

Berdasarkan hasil penelitian diketahui bahwa kekuatan hubungan komunikasi dan disiplin kerja dengan kinerja karyawan yang ditunjukkan oleh nilai koefisien korelasi (r) sebesar 0,651, hal ini berarti bahwa keeratan hubungan antara variabel komunikasi dan disiplin kerja dengan variabel kinerja karyawan kuat. Sedangkan besarnya kontribusi variabel komunikasi dan disiplin kerja terhadap kinerja karyawan yang ditunjukkan oleh nilai $\mathrm{r} 2=0,423$ atau $42,3 \%$. Hasil ini menunjukkan bahwa komunikasi dan disiplin kerja pada PT.Hokben Alam Sutera Tangerang berpengaruh terhadap kinerja karyawan yang meliputi meningkatnya keinginan karyawan meningkatkankinerja karyawan untuk membuktikan kemampuannya. Peningkatan kinerja karyawan tidak lepas dari peran pemimpin pada PT.Hokben Alam Sutera Tangerang yang memiliki kemampuan untuk mengorganisir seluruh kebutuhan organisasi, mampu menciptakan relasi yang baik dengan karyawan, menghargai pendapat karyawan, mampu untuk menjalankan fungsifungsi manajemen yakni kegiatan perencanaan, pengorganisasian, pengaktualisasikan dan pengawasan.

Sedangkan berdasarkan hasil pengujian hipotesis, komunikasi dan disiplin kerja menunjukkan nilai $t_{\text {hitungsebesar } 0,879 \text { pada taraf }}$ signifikan $0,05(5 \%)$ dan nilai $t_{\text {tabel }}$ 
sebesar 2,012. Karena nilai $t_{\text {hitung }}$ komunikasi $>t_{\text {tabel }}(0,879>2,012)$ dan nilai-nilai $\mathrm{t}$ signifikan $>\alpha$ $(0,384>0,05)$, maka dapat disimpulkan bahwa terdapat pengaruh yang signifikan antara komunikasi terhadap kinerja karyawan. Hasil pengujian hipotesis disiplin kerja menunjukkan nilai $t_{\text {hitung }}$ sebesar 3,232 pada taraf signifikan 0,05 (5\%) dan nilai tabel sebesar 2,012. Karena nilai $t_{\text {hitung disiplin kerja }>}$ $t_{\text {tabel }}(3,232>2,012)$, maka dapat disimpulkan bahwa terdapat pengaruh yang signifikan antara disiplin kerja terhadap kinerja karyawan.

Sedangkan uji $\mathrm{F}$ pengaruh komunikasi (X1) dan disiplin kerja (X2) terhadap kinerja karyawan (Y). Dari hasil pengujian statistik di dapat bahwa $F_{\text {hitung }}>F_{\text {tabel }}$ yaitu di dapat bahwa 17,256> 2,81 dengan tingkat signifikan $0,000<$ 0,05 sehingga dapat disimpulkan bahwa terdapat pengaruh yang signifikan komunikasi (X1) dan disiplin kerja (X2) secara simultan terhadap kinerja karyawan (Y).

\section{PENUTUP}

\section{A. Kesimpulan}

Berdasarkan hasil penelitian dan pembahasan yang telah dilakukan peneliti tentang "Pengaruh Komunikasi dan Disiplin Kerja Terhadap Kinerja Karyawan pada PT. Hokben Alam Sutera Tangerang", dikemukakan adalah sebagai berikut:

1. Berdasarkan tanggapan responden mengenai komunikasi pada PT. Hokben Alam Sutera Tangerang adalah baik, karena berdasarkan hasil riset persentase responden yang berjumlah 50 orang dengan 10 pernyataan yang menjawab sangat setuju (SS) ada di poin pernyataan 3 sebanyak 22, yaitu bahwa visi dam misi perusahaan sangat berpengaruh terhadap sikap karyawan. Dan pernyataan yang menjawab setuju (S) ada di poin pernyataan 6 sebanyak 33, yaitu melakukan komunikasi dengan bahasa sehari-hari akan lebih menyenangkan dan dimengerti.

Berdasarkan tanggapan responden mengenai disiplin Kerja karyawan pada PT. Hokben Alam Sutera Tangerang adalah baik, karena berdasarkan hasil riset persentase responden yang berjumlah 50 orang dengan 8 pernyataan yang menjawab sangat setuju (SS) ada di poin pernyataan 3 sebanyak 22, yaitu bahwa balas jasa akan memberikan kecintaan karyawan terhadap perusahaan. Dan pernyataan yang menjawab setuju (S) ada di poin pernyataan 6 sebanyak 34, yaitu bahwa pimpinan harus berlaku adil dan bijaksana dalam pembagian tugas.

2. Pengaruh Komunikasi dan Disiplin Kerja Terhadap Kinerja Karyawa pada PT. Hokben Alam Sutera Tangerang, berdasarkan hasil persamaan regresi bergandaY $=$ $1,070+0,153 \mathrm{X} 1+0,602 \mathrm{X} 2$ yaitu di peroleh nilai sebesar 1,070 , nilai Variabel Komunikasi $\left(\mathrm{X}_{1}\right)$ berpengaruh positif terhadap Kinerja Karyawan (Y) dengan nilai 
koefisiensi sebesar 0,153 , dan Variabel Disiplin Kerja $\left(\mathrm{X}_{2}\right)$ berpengaruh positif terhadap Kinerja Karyawan (Y) dengan nilai koefisien sebesar 0,602, hasil korelasi 0,651 dapat disimpulkan bahwa Pengaruh Komunikasi dan Disiplin Kerja Terhadap Kinerja Karyawan pada PT. Hokben Alam

Sutera Tangerang adalah kuat ada pada interval interpretasi koefisien korelasi, hasil koefisien determinasi Determinasi (R Square) sebesar 0,423 , hal ini menunjukkan bahwa kinerja karyawan (Y) dipengaruhi sebesar 42,3\% sedangkan sisanya sebesar $(100 \%-42,3 \%=57,7 \%)$ dipengaruhi oleh variabel lain yang tidak di teliti oleh peneliti.

Pada uji $F$ pengaruh komunikasi (X1) dan disiplin kerja (X2) terhadap kinerja karyawan (Y), bahwa $F_{\text {hitung }}>$ $F_{\text {tabel }}$ yaitu di dapat bahwa $17,256>2,81$ dengan tingkat signifikasi $0,000<0,05$ sehingga dapat disimpulkan bahwa terdapat pengaruh yang signifikan antara komunikasi (X1) dan disiplin kerja (X2) secara simultan terhadap kinerja karyawan (Y).

Pada Uji t Hasil pengujian hipotesis komunikasi menunjukkan nilai thitung sebesar 0,879 pada taraf signifikan $0,05(5 \%)$ dan nilai $\mathrm{t}_{\text {tabel }}$ sebesar 2,012, Hasil pengujian hipotesis disiplin kerja menunjukkan nilai $t_{\text {hitung }}$ sebesar 3,232pada taraf signifikan $0,05(5 \%)$ dan nilai $t_{\text {tabel }}$ sebesar 2,012, dapat disimpulkan bahwa terdapat pengaruh yang signifikan antara Komunikasi dan Disiplin Kerja Terhadap Kinerja Karyawan pada PT. Hokben Alam Sutera Tangerang.

\section{B. Saran}

Berdasarkan penelitian yang telah dilakukan, peneliti mencoba memberikan beberapa saran yang diharapkan sebagai bahan masukkan untuk PT. Hokben Alam Sutera Tangerang sebagai bahan pertimbangan dalam memberikan kebijakan-kebijakan di masa yang akan datang terkait dengan masalah-masalah yang ditemukan dalam penelitian ini. Adapun saran-saran yang akan peneliti berikan adalah sebagai berikut:

1. Dalam melakukan suatu pekerjaan karyawan harus tanggap dan cepat dalam melaksanakan tugasnya agar yang dilaksanakannya dapat dilakukan dengan baik sesuai SOP dan peraturan perusahaan.

2. Seharusnya pimpinan memberikan teladan yang baik bagi karyawan, sehingga akan berdampak baik pula bagi kelangsungan perusahaan baik itu dari segi karyawan dan tujuan perusahaan itu sendiri.

3. Untuk terus meningkatkan kinerja karyawan pada PT. Hokben Alam Sutera Tangerang, dapat dilakukan dengan cara pihak perusahaan selalu memberikan informasi kepada karyawan untuk selalu mengerjakan tugas sesuai dengan kualitas dan standaritas yang diinginkan oleh perusahaan. 


\section{DAFTAR PUSTAKA}

Bangun, Wilson. 2015. Manajemen Sumber Daya Manusia. Jakarta : Erlangga.

Firmansyah. 2016. Pengaruh Kompensasi terhadap Kinerja Karyawan pada PT. Carrefour Indonesia Cabang Depok. Tangerang Selatan : UniversitasPamulang.

Ghozali, Imam. 2013. Aplikasi Analisisis Multivariate dengan Program IBM SPSS 21 Update PLS Regresi, Edisi 7. Cetakan ketujuh. Semarang : Badan Penerbit-Undip.

Handoko, T Hani. 2013. Manajemen Personal dan Sumber Daya Manusia. Yogyakarta: BPEE Yogyakarta. Hasibuan, Malayu S.P. 2014. Manajemen Sumber Daya Manusia. Jakarta : PT. Bumi Aksara.

Indrasari, Meithiana. 2017. Kepuasan Kerja dan Kinerja Karyawan. Edisi Pertama. Yogyakarta : Indomedia Pustaka.

Kasmir. 2016. Manajemen Sumber Daya Manusia. Jakarta: PT Raja Grafindo Persada.

Mangkunegara,Prabu Anwar.2015.Manajemen

Sumber Daya Manusia Perusahaan. Cetakan kedua belas. Bandung : Remaja Rosdakarya.
Mulyadi . 2015. Manajemen Sumber Daya Manusia (MSDM). Jakarta:IN Medi- Anggota IKAPI.

Purwanto, Djoko. 2011. Komunikasi Bisnis. Jakarta: PT. Gelora Aksara Pratama. Riadi, Edi. 2016. Statistika Penelitian (Analisis Manual dan IBM SPSS). Yogyakarta : Andi Offset.

Riduwan, Adun Rusyana dan Enas. 2013. Cara Mudah Belajar SPSS 17.0 dan Aplikasi Statistik Penelitian. Bandung : Alfabeta.

Ruslan, Rosady. 2010. Manajemen Public Relations dan Media Komunikasi. Jakarta: Rajawali Pers.

Sedarmayanti. 2011. Manajemen Sumber Daya Manusia. Bandung: PT. Refika Aditama. Simamora, Hendry. 2014. Manajemen Sumber Daya Manusia. Yogyakarta: STIES YKPN.

Sugiyono. 2011. Metodologi Penelitian : Kuantitatif, Kualitatif. Bandung: Alfabeta. Sutrisno, Edy. 2015. Manajemen Sumber Daya Manusia, Edisi ketujuh. Jakarta: Kencana Prenada Media Group.

Yani, M. 2012. Manajemen Sumber Daya Manusia. Jakarta: Mitra Wacana. 